\title{
PACIFIC NORTHWEST REGIONAL ASSESSMENT: THE IMPACTS OF CLIMATE VARIABILITY AND CLIMATE CHANGE ON THE WATER RESOURCES OF THE COLUMBIA RIVER BASIN1
}

\author{
Edward L. Miles, Amy K. Snover, Alan F. Hamlet, Bridget Callahan, and David Fluharty 2
}

\begin{abstract}
The Pacific Northwest (PNW) regional assessment is an integrated examination of the consequences of natural climate variability and projected future climate change for the natural and human systems of the region. The assessment currently focuses on four sectors: hydrology/water resources, forests and forestry, aquatic ecosystems, and coastal activities. The assessment begins by identifying and elucidating the natural patterns of climate variability in the PNW on interannual to decadal timescales. The pathways through which these climate variations are manifested and the resultant impacts on the natural and human systems of the region are investigated. Knowledge of these pathways allows an analysis of the potential impacts of future climate change, as defined by IPCC climate change scenarios. In this paper, we examine the sensitivity, adaptability and vulnerability of hydrology and water resources to climate variability and change. We focus on the Columbia River Basin, which covers approximately 75 percent of the PNW and is the basis for the dominant water resources system of the PNW. The water resources system of the Columbia River is sensitive to climate variability, especially with respect to drought. Management inertia and the lack of a centralized authority coordinating all uses of the resource impede adaptability to drought and optimization of water distribution. Climate change projections suggest exacerbated conditions of conflict between users as a result of low summertime streamflow conditions. An understanding of the patterns and consequences of regional climate variability is crucial to developing an adequate response to future changes in climate.

(KEY TERMS: integrated regional assessment; climate sensitivity and vulnerability; management adaptability; long-term water resources planning; hydroclimatology; Columbia River Basin; climate variability; climate change.)
\end{abstract}

\section{INTRODUCTION}

The Pacific Northwest Regional Assessment is an inter-disciplinary research effort to understand the impact of climate on natural and human systems within the region. It is being conducted by the Joint Institute for the Study of the Atmosphere and Ocean/School of Marine Affairs Climate Impacts Group at the University of Washington. For the purposes of the assessment, the Pacific Northwest (PNW) is defined as the states of Washington, Oregon and Idaho and all of the Columbia River Basin.

We began the regional assessment by elucidating the patterns of natural climate variability in the PNW; i.e., examining changes in average weather conditions on time scales ranging from seasonal/interannual to interdecadal. This effort relies primarily on instrumental records of temperature and precipitation (c. 120 years) and is being extended back in time through paleoclimatic reconstructions using tree rings, sediment cores, and other proxies. The emphasis is placed on understanding natural variations in the large scale physical climate in order to address the resultant variations in the environmental (ocean/atmosphere/terrestrial) systems of the PNW region.

Next, we assessed the impacts of climate variability on natural systems within four sectors: hydrology/water resources, forests and forestry, aquatic ecosystems, and coastal activities. We also assessed

1Paper No. 99074 of the Journal of the American Water Resources Association. Discussions are open until December 1, 2000.

2Respectively, Bloedel Professor of Marine Studies and Public Affairs, Principal Investigator, JISAO/SMA Climate Impacts Group, University of Washington, 4909 25th Ave. N.E., Seattle, Washington 98105; Post-Doctoral Research Associate, JISAO/SMA Climate Impacts Group, University of Washington, 4909 25th Ave. N.E., Seattle, Washington 98105; Research Scientist, Department of Civil and Environmental Engineering, JISAO/SMA Climate Impacts Group, University of Washington, 4909 25th Ave. N.E., Seattle, Washington 98105 ; Coastal Management Fellow, NOAA, Kachemak Bay National Estuarine Research Reserve, 202 West Pioneer Ave., Suite B, Homer, Alaska 99603; and Professor, School of Marine Affairs, Senior Faculty; JISAO/SMA Climate Impacts Group, University of Washington, 4909 25th Ave. N.E., Seattle, Washington 98105 (E-Mail/Miles: edmiles@u.washington.edu). 
the climate impacts to, and the responses of, the human socioeconomic and political systems within each sector. The time scale of climate variability we examined, i.e., seasonal/interannual to interdecadal, is consistent with that on which societal response strategies to changes in climate are framed.

The responses of natural and human systems to natural climate variability provide a framework for understanding how the same systems might respond to future climate change. We assessed the impacts of climate change using projected changes in PNW temperature and precipitation from Intergovernmental Panel on Climate Change (IPCC) climate change scenarios for the decades of 2020 and 2040. In our assessment of the impacts of both climate variability and change, we differentiated between climateinduced and anthropogenic effects as agents of change within each sector.

The regional assessment focused on three questions:

1. How sensitive is the PNW to climate variability?

2. How adaptable is the PNW to climate variability and change?

3. How vulnerable is the PNW to climate variability and change?

This approach was taken from IPCC (1996b), where these terms were defined as follows:

Sensitivity is the degree to which a system will respond to a change in climatic conditions.

Adaptability refers to the degree to which adjustments in systems' practices, processes, or structures to projected or actual changes of climate are possible. Adaptation can be spontaneous or planned, and can be carried out in response to or in anticipation of changes in conditions.

Vulnerability defines the extent to which climate change may damage or harm a system. It depends not only on a system's sensitivity but also on its ability to adapt to new climatic conditions.

The final stage in the assessment was an evaluation of the capacity of existing institutional arrangements to respond effectively to the scope of changes in the climate scenarios. The emphasis was on assessing the region's planning, adaptation, and mitigation capabilities on an aggregated regional, as well as a sector-by-sector, basis. Alternative options for improving response capacity and reducing vulnerability were also identified and evaluated.
In this paper we present the framework of the integrated regional assessment developed for the PNW. We highlight specific findings to illustrate the power of this approach. Specifically, we focus on the impacts of climate variability and climate change on hydrology and water resources. This provides a basis for impact studies in the other three sectors, as the region's hydrology plays a critical role in translating climate fluctuations into sectoral impacts. Although the regional assessment project examines climate impacts throughout the entire PNW, we confine our discussion in this paper to the impacts on the region defined by the Columbia River Basin (Figure 1). The Columbia River, one of the largest in North America, drains approximately 75 percent of the PNW, accounting for 55-65 percent of the total runoff from the region. It is the basis for the dominant water resources system of the PNW.

\section{REGIONAL PATTERNS OF CLIMATE VARIABILITY}

We examine patterns of climate variability in the PNW by focusing on the regional impacts of two planetary-scale climate phenomena: the El Niño/ Southern Oscillation (ENSO) and the Pacific Decadal Oscillation (PDO). ENSO is the planet's dominant mode of climate variability on the seasonal to interannual time scale (Rasmussen and Wallace, 1983). El Niño refers to a suite of anomalous climate conditions in the tropical Pacific characterized by unusually warm sea surface temperatures (SSTs) and weak trade winds, while La Niña refers to the climate state characterized by anomalously cool SSTs and stronger than average trade winds. ENSO events have pronounced global climatic consequences, affecting the PNW on interannual timescales in a manner which will be described below.

The PDO has been described as a long-lived ENSOlike pattern of Pacific climate variability (Zhang et $a l .$, 1997). As is the case for El Niño and La Niña, extremes in the PDO pattern are marked by widespread climatic variations in the Pacific Basin and North America. Two main characteristics distinguish the PDO from ENSO. First, typical PDO "events" have shown remarkable temporal persistence relative to that attributed to ENSO events. In this century, major PDO regimes have persisted for 20 to 30 years. Second, the climatic fingerprints of the PDO are most visible in the region of the North Pacific and North America, with secondary climatic influences in the tropics. The opposite is true for ENSO (Zhang et al., 1997; Mantua et al., 1997). 


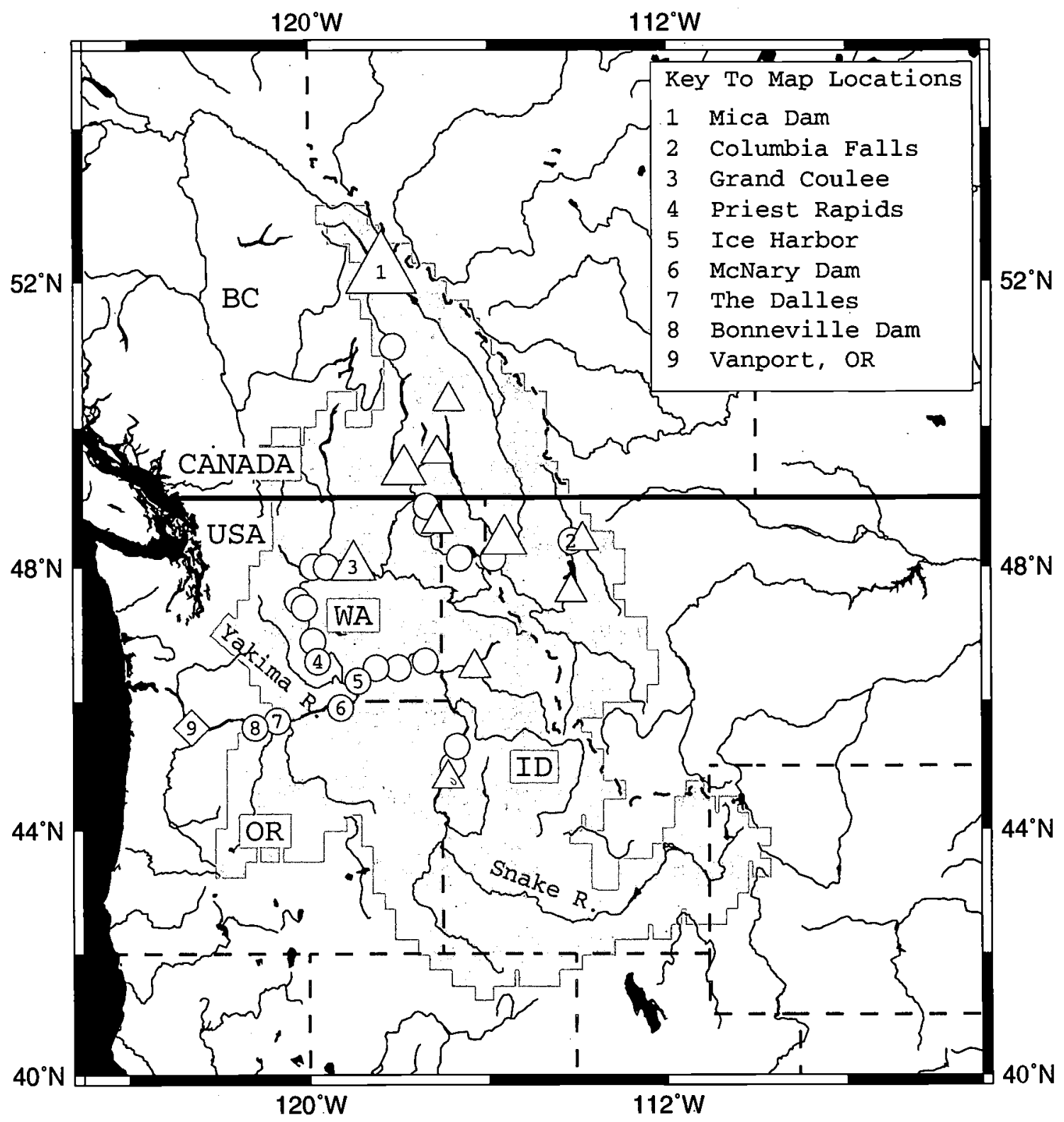

Figure 1. The Columbia River Basin and Major Dams. The gray shaded area indicates the drainage basin upstream of The Dalles, Oregon. Triangles represent major storage reservoirs (size of icon represents relative storage capacity), circles are major run-of-river projects.

Several independent studies find evidence for two full PDO cycles in the past century: cool PDO regimes lasted from 1890 to 1924 and again from 1947 to 1976, while warm PDO regimes spanned 1925 to 1946 and from 1977 through at least the mid-1990s (Minobe, 1997; Mantua et al., 1997). Recent evidence suggests that the PDO may have switched to a cool phase before 1997 (Hamlet and Lettenmaier, 1999a). Causes for the PDO are unknown (National Research Council, 1998).

These two large-scale patterns of climate variability have similar influences on the climate of the PNW. El Niño and warm PDO eras increase the likelihood for anomalously warm and dry winter and spring weather in the PNW. La Niña and cool PDO periods increase the likelihood that PNW winter and spring weather will be anomalously cool and wet (Redmond, and Koch, 1991; Mantua et al., 1997). Recent work suggests that interactions between the PDO and ENSO can enhance these patterns of variability. The likelihood for warm-dry winter/spring conditions in the PNW is especially high in years when El Niño coincides with a warm phase of the PDO. Coincidence of La Niña and a cool phase of the PDO leads to an increased likelihood for cool-wet winter/spring conditions in the PNW (Gershunov and Barnett, 1998). 
However, other combinations of ENSO and PDO conditions have coincided with poor event-to-event coherence in patterns of PNW climate anomalies, with probabilities for anomalous climate conditions essentially the same as those for all non-ENSO years.

\section{WHAT IS THE SENSITIVITY OF THE COLUMBIA RIVER BASIN TO CLIMATE VARIABILITY?}

\section{Hydrologic Response}

Annual flow in PNW rivers is predominantly determined by winter (October to March) precipitation. Variations in regional temperature and basin topography determine whether this precipitation accumulates as snow or falls as rain. In the spring, the accumulated snow (if any) melts, contributing to spring and summer streamflow. For low-lying rivers on the west side of the Cascade Mountain range, where temperatures are usually above freezing, most of the winter precipitation falls as rain and little water is stored in the snow pack. In intermediate elevation basins on the west side, runoff is dominated by precipitation falling as rain during the fall and early winter and by the springtime melt of precipitation stored as snow during the mid-winter and at higher elevations. Rivers east of the Cascades tend to be snowmelt dominated. Most of the winter precipitation falls as snow, which melts in the spring, creating a characteristic low-flow period in winter followed by large spring/summer peak flows. The Columbia River, which comprises rain-dominated, rain/snow-dominated and snow-dominated subbasins, is dominated by snowmelt.

Seasonal patterns of streamflow are crucial for regional hydropower, fisheries resources, irrigated agriculture and municipal drinking water systems. Figure 2 shows a schematic of some key components of the hydrologic water balance and its implications for the regional assessment. Because the regional hydrologic response is a dominant impact pathway for climate impacts in the PNW, understanding climate impacts to the region's hydrology provides the foundation for an investigation of climate impacts to other natural systems within the region.

The hydrology of the PNW is strongly influenced by the patterns of climate variability identified above. Because PDO and ENSO extremes change the odds that PNW winters will be warm and dry or cool and wet, their occurrence tends to influence the region's characteristic hydrological patterns. For each of the PNW river types, warm, dry winters tend to produce low winter runoff, low snow pack accumulation, early spring melt, and reduced spring and summer streamflow due to both decreased snow pack and increased evapotranspiration. Overall, streamflow is reduced. Cold, wet winters tend to produce the opposite effects in each case.

The response of Columbia River streamflow to PDO and ENSO oscillations is illustrated by composite averages of streamflow during the two phases of each climate phenomenon (Figure 3 ). These composites were created using monthly records of naturalized flows at The Dalles, Oregon for 1900-1998, with PDO epochs as defined above. El Niño (La Niña) years

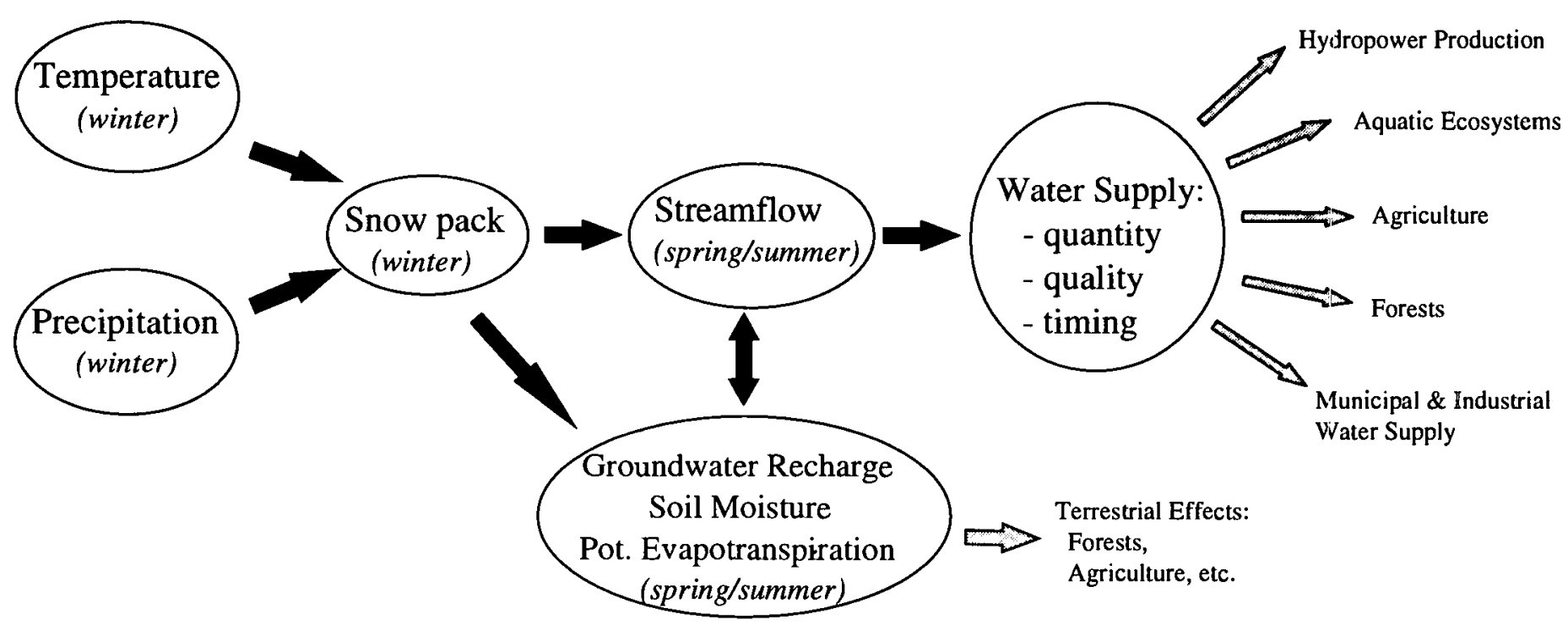

Figure 2. The Dominant Impact Pathway Through Which Changes in Regional Climate Are Manifested in the Pacific Northwest. 
Pacific Northwest Regional Assessment: The Impacts of Climate Variability and Climate Change on the Water Resources of the Columbia River Basin

(a)

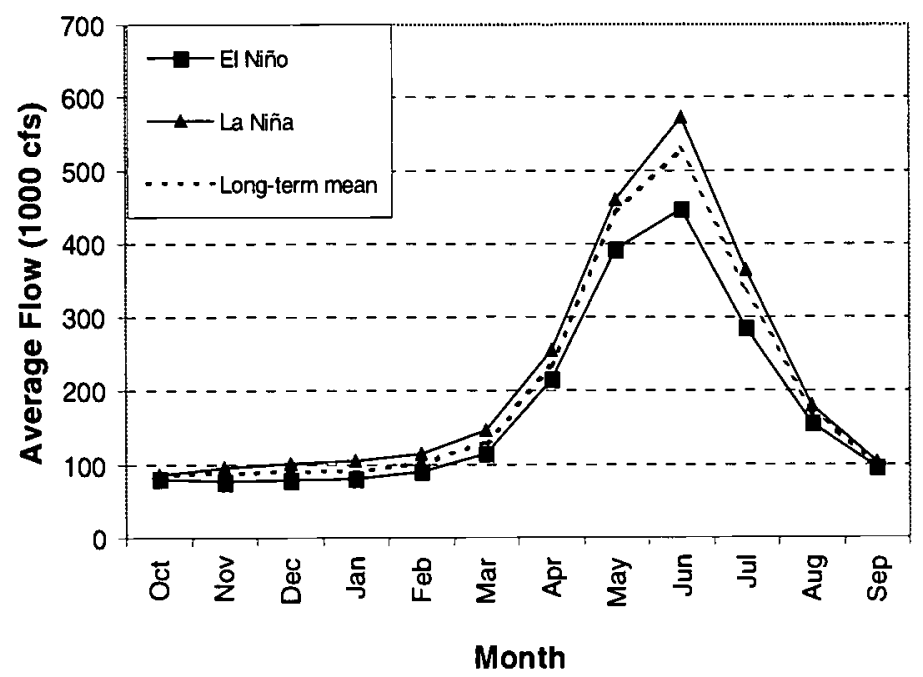

(b)

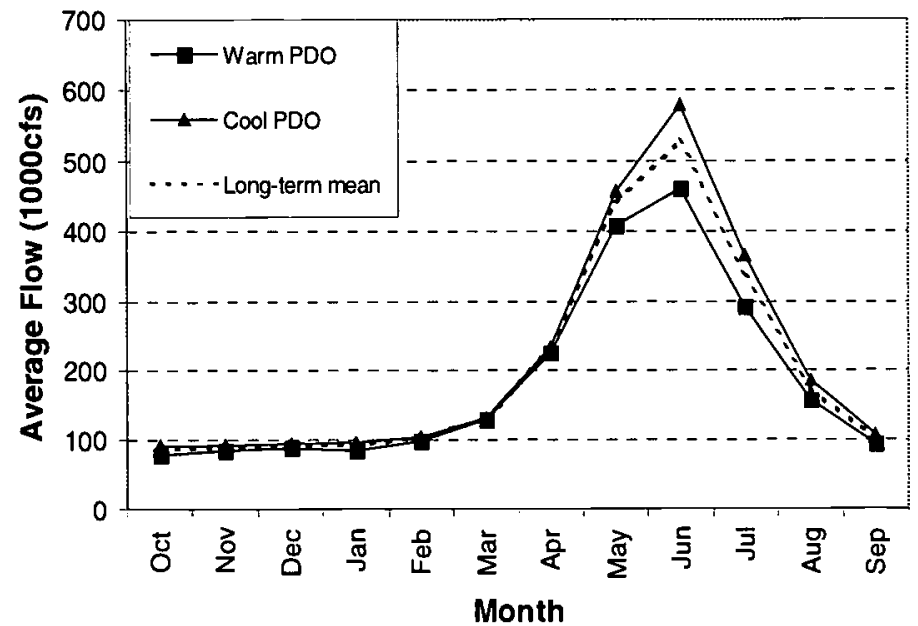

(c)

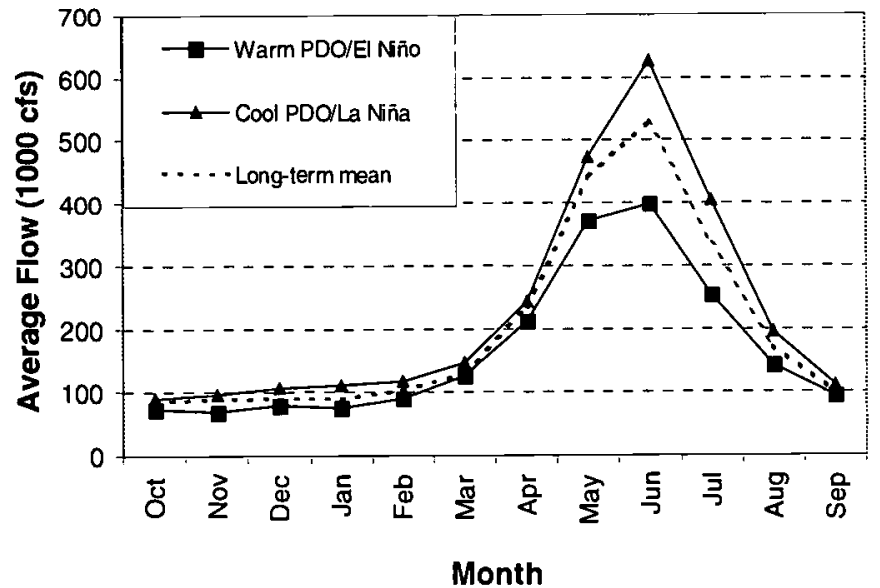

Figure 3. ENSO and PDO Composite Hydrographs for the Columbia River Basin. Composite hydrographs for 1900-1998 Columbia River naturalized streamflows at The Dalles, Oregon, during alternative phases of (a) ENSO, (b) the PDO, and (c) during warm PDO/El Niño and cool PDO/La Niña years. Dashed lines represent the long-term mean. ENSO years and PDO epochs are as defined in the text.

Naturalized flow represents "virgin" streamflow, in which estimated human impacts on the river have been removed (see text). 
were defined as those years for which the December to February NINO3.4 index (Trenberth, 1997) exceeds 0.5 standard deviations above (below) its long-term (1900-1996) mean value. Naturalized flow represents "virgin" streamflow, in which estimated human impacts, i.e., the effects of storage, irrigation, and increased evaporation from reservoirs, have been removed. The time series of naturalized flows used throughout this manuscript was derived by the Climate Impacts Group (N. Mantua, JISAO/SMA Climate Impacts Group, personal comm.) based on naturalized flow estimates for 1928-1988 from the BPA (Nancy Stephans, BPA, personal comm.). Naturalized flows for 1989 to present and for prior to 1928 were calculated based on methods developed by the BPA to convert gage flows to naturalized flows.

During El Niño and warm PDO years (La Niña and cool PDO years) streamflow tends to be lower (higher) than average, although large variability exists within each climate category. The most significant shifts in the probability for altered streamflow occur during the spring/summer, i.e., April through September, with the largest shifts occurring during peak flows in June (Figure 3). During an average El Niño year, annual Columbia River streamflow is 12 percent lower than the long-term average, while in the average La Niña year it is about 8 percent higher than the mean. Similarly, in warm PDO eras, annual average Columbia River streamflow is 9 percent below the long-term mean, while during cool PDO regimes it averages about 6 percent above the mean. Average flow anomalies are most pronounced during years in which ENSO and the PDO are in phase (e.g., warm $\mathrm{PDO} / \mathrm{El} \mathrm{Niño}$ ), indicating that these two climate effects are at least partially independent and can reinforce each other. During warm PDO/El Niño years, streamflow is on average 17 percent below the mean, while in cool PDO/La Niña years flow tends to be about 14 percent higher than average.

Two extremes that any water management system must deal with are unusually high and low streamflows. The estimated probabilities for these conditions on the Columbia during different phases of ENSO and the PDO are shown in Table 1. For the purpose of this discussion, anomalous streamflow is defined as
April to September average naturalized flows at The Dalles, Oregon, more than 1.5 standard deviations from the long-term (water years 1900-1997) average flow. This corresponds to $1: 28$ percent and 72 percent of the long-term mean for high and low flows, respectively (Table 2). Flow anomalies of this size can significantly decrease the Columbia River water management system's ability to meet water resources objectives, as will be discussed below.

TABLE 1. Observed Probability of High and Low Streamflows in the Columbia River Basin Associated With EINSO and the PDO. ENSO years and PDO epochs are defined as described in the text. Probabilities are computed using naturalized flows at The Dalles for 1900-1998. Low (high) streamflow is defined as April to September average flow more than 1.5 standard deviations below (above) the historical mean April to September flow. See Table 2 for the observed historical distribution of Columbia River streamflow.

\begin{tabular}{lcc}
\hline \multicolumn{1}{c}{ Climate Category } & $\begin{array}{c}\text { Probability of } \\
\text { LOW FLOW } \\
\text { (percent) }\end{array}$ & $\begin{array}{c}\text { Probability of } \\
\text { HHGH FLOW } \\
\text { (percent) }\end{array}$ \\
\hline All Years (1900-1998) & 8 & 7 \\
Warm PDO & 14 & 0 \\
Cool PDO & 4 & 12 \\
El Niño & 21 & 0 \\
ENSO Neutral & 0 & 9 \\
La Niña & 3 & 12 \\
& & \\
Warm PDO/El Niño & 36 & 0 \\
Warm PDO/ENSO Neutral & 0 & 0 \\
Warm PDO/La Niña & 8 & 0 \\
Cool PDO/El Niño & 11 & 0 \\
Cool PDO/ENSO Neutral & 0 & 18 \\
Cool PDO/La Niña & 0 & \\
\hline
\end{tabular}

During this century, anomalously high April to September average streamflow has never been observed during warm PDO epochs or during El Niño years (Table 1). Instead, these years exhibit an increased probability for low flows. Cool PDO and La Niña years both exhibit an enhanced probability of

TABLE 2. Historical Distribution of Columbia River Streamflows at The Dalles, Oregon (1900-1998). This distribution was calculated using total water year (October-September) flows derived from monthly records of naturalized streamflow and indicates the range of natural variability in Columbia River flow. Because annual streamflow in the Columbia is dominated by summertime flow, the historical distribution of summer (April-September) streamflow is essentially equal to that shown below for annual flows.

\begin{tabular}{lccccccccc} 
Flow Anomaly, & -2.0 & -1.5 & -1.0 & -0.5 & 0 & 0.5 & 1.0 & 1.5 & 2.0 \\
Standard Deviations ( $\sigma)$ & & & & & & & & \\
Percent Normal Flow & 64 & 73 & 82 & 91 & 100 & 109 & 118 & 127 & 136 \\
\hline
\end{tabular}


high flows compared to the long-term record as a whole. The largest probability shift for streamflow occurs when the climate patterns are in phase, consistent with similar probability shifts for PNW temperature and precipitation (Gershunov and Barnett, 1998). During warm PDO/El Niño years, the probability of anomalously low streamflow is 36 percent, compared to a probability of 8 percent in the record as a whole. During cool PDO/La Niña years, the probability of anomalously high streamflow is 19 percent, compared to 7 percent in the overall historical record.

\section{Sensitivity of the Water Resources Management System}

The Columbia River is clearly responsive to climate variability. Compared to other major North American rivers, the variability of Columbia River streamflow is relatively low. The coefficient of variation, that is, the ratio of the standard deviation of streamflow to the historical mean flow, is $\sim 20$ percent for the Columbia (Table 2). In contrast, the coefficients of variation for the Mississippi and Missouri Rivers are 56 percent and 40 percent, respectively (Yevdjevich, 1963). Hydrologic sensitivity is only part of the story; the important question is how well does the Columbia River water resources system cope with climate variability? Put another way, how do variations in climate affect those who depend on the water resources of the Columbia River Basin?

Answering this question requires an examination of the management structure of the Columbia River system. The Columbia River water management system comprises over 250 dams, each with complicated operating procedures (Bonneville Power Administration et al., 1995; hereinafter BPA et al., 1995). It was originally designed to meet the region's needs for flood control, hydropower, irrigation and navigation.

More recently, use of water resources for fish and wildlife protection, water quality, and recreation have become more important as the region has grown and environmental values have changed (BPA et al., 1995). Specifically, the Pacific Northwest Power Planning and Conservation Act (NPA) of 1980 called for fish to receive equitable treatment in comparison to hydropower (Wood, 1993; Callahan et al., 1999). In addition, the listing of several salmon stocks as endangered or threatened under the Endangered Species Act (ESA) during the 1990s has given anadromous fish stocks high priority for management agencies. The ESA prohibits any federal agency from actions that would jeopardize these species or their critical habitat. Various agreements have established instream flow targets for fisheries protection. The
1988 Vernita Bar Agreement aims to protect fall Chinook salmon spawning grounds near Priest Rapids in the Hanford Reach and the 1995 National Marine Fisheries Service and U.S. Fish and Wildlife Service Biological Opinions (NMFS, 1995) established system-wide flow targets for the overall protection of anadromous fish.

The various water uses in the Columbia River Basin have unique and often competing requirements for optimal timing of flows (BPA et al., 1995; Callahan et al., 1999). As a result of fisheries protection efforts, there is increased pressure for streamflow patterns to resemble natural conditions more closely, with a large spring freshet. This conflicts with hydropower production and flood control objectives which have the effect of decreasing spring peak flows (Hamlet and Lettenmaier, 1999b). Details of the conflicting reservoir operation objectives among other water uses are reviewed in Callahan et al. (1999).

Determining whether climate-induced variability in streamflow affects water users requires an understanding of how the entire water management system copes with natural variations in streamflow amount and timing. However, there is no single, coordinated, prioritized system of operating procedures established to ensure that the various water use objectives established in the Columbia River Basin are achieved. Only in the cases of hydropower production and flood control is the Columbia River system managed and operated as a whole (BPA et al., 1995). Operating procedures established for the remaining water uses call for certain rule curves and storage allocations at various individual dams within the system. Although water supply objectives have been articulated with regard to each individual water use, the system is not generally managed as a whole and the conditions under which the various competing water use objectives can be satisfied are unclear.

Columbia River Water Resources Model. Reservoir operations models offer opportunities to examine complicated water management systems as a whole and probe their sensitivities to climate variability. The ColSim reservoir operations model is a monthly timestep model simulating the major features of the Columbia River water resources system under the current operating policies (Hamlet and Lettenmaier, 1999b). ColSim was developed at the University of Washington as a research and planning tool for understanding seasonal effects and climate impacts on the water resources system of the Columbia River Basin. The model represents the major storage reservoirs, run of river dams, diversions and return flows, from Mica Dam in British Columbia to Bonneville Dam near the mouth of the river, including the Kootenai, Pend Oreille, Clark 
Fork, and Snake River systems (Figure 1). The dams on the Yakima and Spokane rivers, as well as those on numerous smaller tributaries, are not simulated. Operations at 13 major storage dams and 20 run-ofriver dams are simulated, that is, simplified versions of current operations for hydropower production, major flow target support (for fisheries protection), agricultural withdrawals and flood evacuation. The model is driven by monthly streamflow data (either observed or simulated).

ColSim incorporates the major demands on the water resources system that affect water allocation under the current reservoir operating rules. The system objectives examined here are flood control, hydropower production, agricultural diversions from the Middle Snake River, navigation, recreation and maintenance of instream flow targets for fisheries protection (Table 3). Both system-wide instream flow targets (McNary dam) and flow targets for specific locations within the river (Priest Rapids and Columbia Falls) are examined. In the model, as in the actual system, critical period analysis and winter streamflow forecasts are used to determine the operational rule curves for January through July (the "variable period") that specify the amount of spring storage evacuation for flood control and limits to hydropower releases at major dams. From August through December (the "fixed period"), operations are guided by critical period analysis. Details of how the system objectives are simulated by ColSim and validation studies showing that the model reproduces well the observed macro-scale response of the actual Columbia River system to streamflow variability can be found in Hamlet and Lettenmaier (1999b).

\section{Climate Sensitivities and Operating Priori-} ties. The ability of the Columbia River water resources system to meet competing use objectives in the face of natural streamflow variability was evaluated using the ColSim reservoir operations model. The model simulated current operating procedures with regards to the multiple water resources objectives supported by the Columbia River water management system (as described above) for the period from 1931 to 1989 . Modified flows (A.G. Crook Company, 1993) were used to drive the model. Modified flows are estimated naturalized flows that have been adjusted to contain the effects of the relatively small irrigation diversions and evaporation effects in most of the Columbia River Basin. Naturalized flows

TABLE 3. Columbia River Basin Reservoir System Objectives Evaluated by the ColSim Reservoir Operations Model. See Hamlet and Lettenmaier (1999b) for a description of how the ColSim model simulates these objectives.

See Figure 1 for locations within the Basin.

Water Use

Hydropower Production

Firm Energy

Non-Firm Energy

Flood Control

Instream flows

Agricultural Diversions

Recreation

Navigation
System Objective
Annual system-wide energy target of $72 \times 10^{6} \mathrm{MW}$-hr supplied by the major dams operating under the Pacific Northwest Coordination Agreement (PNCA). The monthly firm energy target follows the characteristic seasonal load shape (BPA et al., 1994).

Annual system-wide energy target for characteristic seasonal load shapes (BPA et al., 1994) of $19 \times 10^{6}$ MW-hr using only major PNCA dams and only when the dams are above the energy content curve. In low flow years, non-firm energy production may be threatened when firm energy production is not.

Maintenance of monthly-average flows below $400,000 \mathrm{cfs}$ at The Dalles.

Proposed (monthly-varying) instream flow targets for resident fish protection at :

(1) McNary dam on the mainstem, to ensure adequate flow in the river as a whole for overall anadromous fish protection (NMFS, 1995);

(2) Priest Rapids, to protect the fall Chinook spawning grounds at Hanford Reach under the Vernita Bar agreement; and

(3) Columbia Falls, to support fish recovery activities for Kokanee salmon.

Sufficient supply to satisfy irrigation demand, quantified as withdrawals equal to 90 percent of estimated 1989 diversions from the middle Snake River.

Maintenance of a minimum elevation of 1280 feet (above sea level) for Lake Roosevelt at the Grand Coulee dam from July 1 through Labor Day.

Maintenance of flows above 100,000 cubic feet/second at Ice Harbor in the lower Snake River. 
were used for simulating the upper and middle Snake River, since ColSim explicitly models the irrigation diversions in this part of the basin (Hamlet and Lettenmaier, 1999b). Water years within this time series were categorized according to flow anomaly [standard deviations ( $\sigma$ ) from the 1900-1997 longterm annual mean] (Table 2). Within each flow category, operational performance was evaluated for the suite of water resources system objectives listed in Table 3. Performance was measured using reliability, i.e., the observed probability of meeting the objective within each flow category.

We examined the flow anomaly at which the reliability of meeting each water resources objective decreased to 85 percent. A reliability of 85 percent is presumably low enough that impacts will be felt by the water user; however, this analysis does not attempt to quantify such impacts. Nor do we attempt to rank the severity of impacts across the different water uses. The economic, institutional or social impacts of a 15 percent failure in one system objective may be significantly different than those resulting from the same failure rate in another objective. An evaluation of the relative severity of impacts would clearly be required before using this information to inform policy decisions affecting water use priorities.

The sensitivity of a water use objective to climate variability is indicated by the degree to which streamflow has to deviate from the norm before the reliability of meeting that system objective decreases to 85 percent. The lower the (absolute) value of the flow anomaly corresponding to a reliability of 85 percent, the higher the sensitivity to climate variability. Figure 4 shows the flow anomalies associated with a reliability of 85 percent for the system objectives defined in Table 3. The reliabilities of achieving McNary flow targets and middle Snake agricultural withdrawals decrease to 85 percent when flow is more than $0.1 \sigma$ below average. Non-firm energy does not fall below 85 percent reliability until flows are more than $1.5 \sigma$ below average. Thus, the McNary flow target is more vulnerable to low flow conditions than is non-firm energy production under the current operating system.

Firm energy production and the Priest Rapids and Columbia Falls flow targets are shown in Figure 4 to be 85 percent reliable at a flow anomaly of $-3 \sigma$. These objectives were actually simulated to be 100 percent reliable by the model for the period of study, during which time the lowest observed annual streamflow was $-2.33 \sigma$ for water year 1977 . The invulnerability of firm energy targets to climate variability is not surprising since this was the essential criterion for determining the amount of energy production assigned to the hydro-system (BPA et al., 1991). The Priest Rapids and Columbia Falls instream flow targets are robust to natural climate variability due to upstream storage that can be used to satisfy these flow requirements.

System objectives for navigation and flood control are adversely affected by higher than average flows. Because the reliability of meeting navigation objectives decreases first when flow increases, navigation objectives are more vulnerable than flood control to high flow conditions. Thus, the reliability of some primary water resources objectives will vary significantly from year to year as a result of natural climate variability, while the reliability of other uses is essentially isolated from climate by the design of the operating system.

The model results shown in Figure 4 indicate the order in which water use objectives are affected by high and low streamflows. They therefore define the de facto system operating priorities. For uses impacted by high flow conditions, flood control at The Dalles (85 percent reliable at $+2 \sigma$ ) is of higher de facto priority than navigation ( 85 percent reliable at $+0.7 \sigma$ ). For uses impacted by low flow conditions, the decreasing order of de facto priority within the system is: firm energy production (100 percent reliable), fisheries flow targets at Priest Rapids and Columbia Falls (100 percent reliable), non-firm energy (threshold of 85 percent reliability at $-1.5 \sigma$ ), Lake Roosevelt Recreation ( 85 percent reliable at $-0.2 \sigma$ ), and middle Snake River irrigation and the McNary Flow Target (85 percent reliable at $-0.1 \sigma$ ). Because the system-wide instream flow target for fisheries protection is supported by a much lower percentage of available system storage compared to that allocated for energy production, it is much more vulnerable to streamflow variability and can only be fully satisfied when streamflow is near or above average.

These de facto priorities of the operating system are not in keeping with legislative policy established by the NPA for the Columbia River which called for fisheries protection and hydropower production to be of equal priority. This indicates that the water resources operating system is, by design, sub-optimal in this regard. However, in evaluating parity between these competing uses, it is important to note that firm energy power production levels have declined recently with changes in the operating system resulting from the institution of instream flow targets. In addition, efforts to improve the status of anadromous fish runs have not been limited to maintenance of instream flows. Other types of mitigation, such as dam bypass facilities and transportation programs for juvenile fish, have also been adopted. Nonetheless, state and federal fish and wildlife agencies and regional Indian tribes have long argued that the power planning process does not consider anadromous fish protection and power production of equal priority (Wood, 1993), a 
(a)

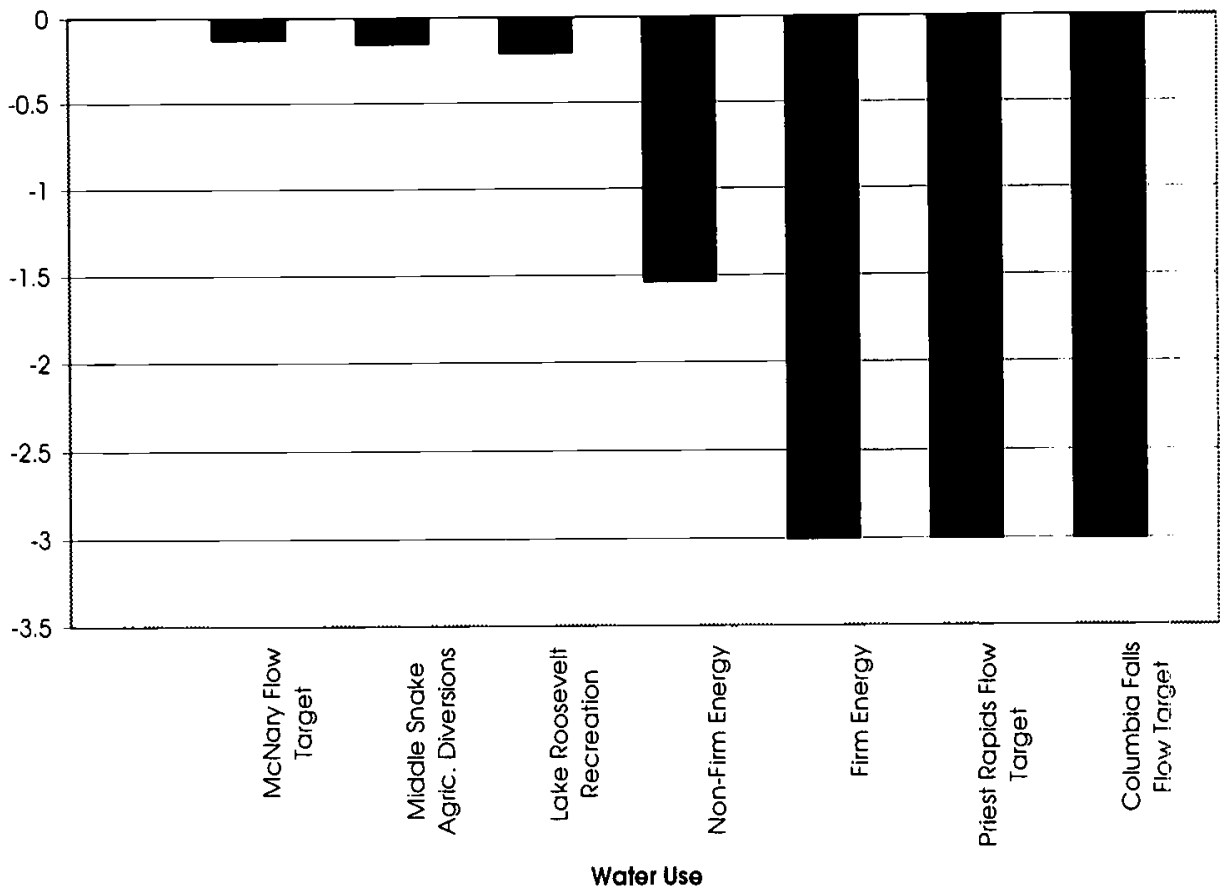

(b)

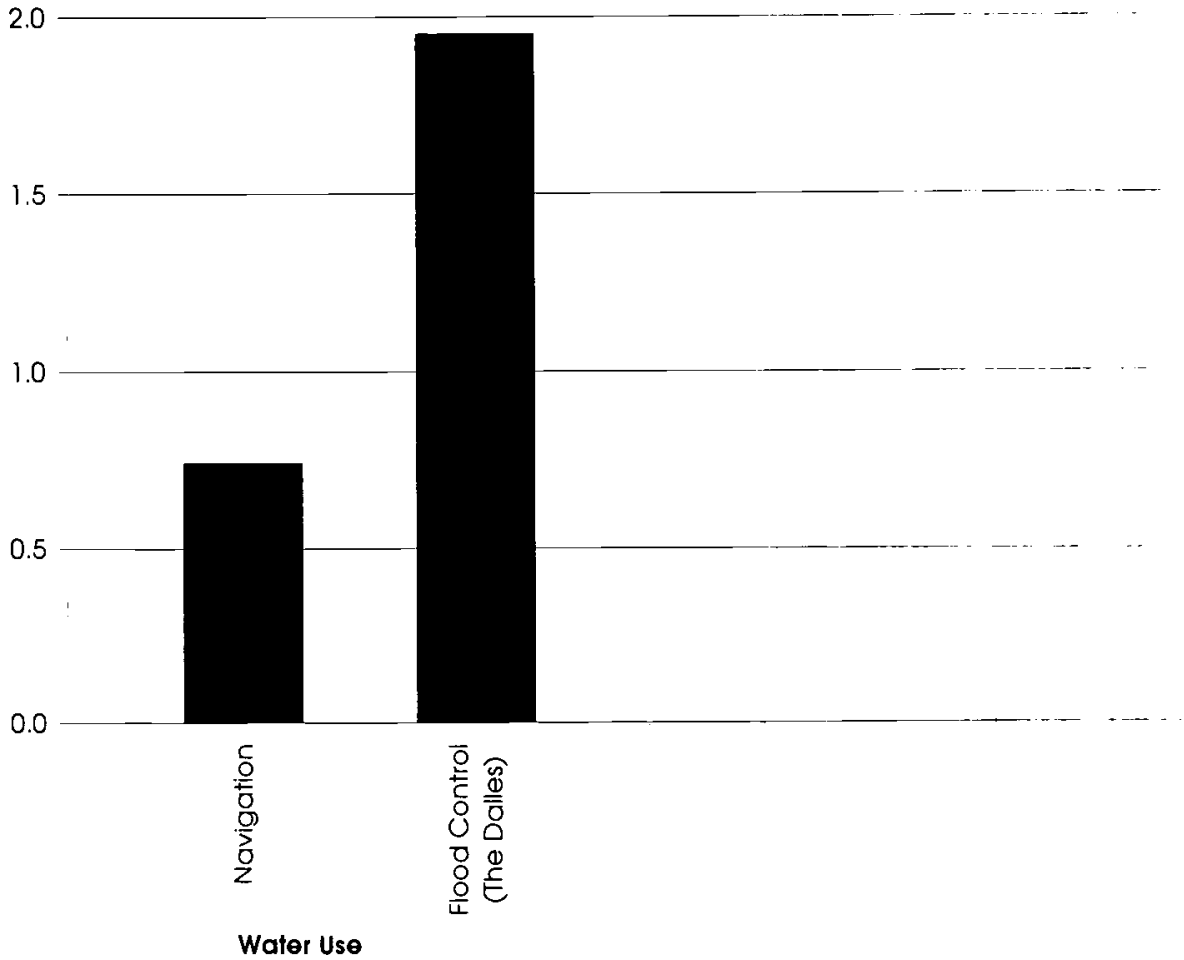

Figure 4. The Sensitivity of Columbia River Water Resource Objectives to Natural Streamflow Variability. Shown are flow anomalies at which each objective decreases to a reliability of 85 percent, as modeled by the ColSim reservoir model (see text). (a) Thresholds for reliability of uses impacted by low flow.

Note that firm energy production and the Priest Rapids and Columbia Falls flow targets are simulated by the model to be 100 percent reliable for the entire study period (see text).

(b) Thresholds for reliability of uses impacted by high flow. Water use objectives are defined in Table 3 
perception that is unlikely to change when instream flow targets are inconsistently met.

\section{WHAT IS THE ADAPTABILITY OF THE COLUMBIA RIVER BASIN TO CLIMATE VARIABILITY?}

The overall adaptability of the Columbia River Basin to climate variability is determined by total storage capacity of the water resources system, priorities and patterns of reservoir operations, fluctuating demand for water, and patterns of conflict between different governmental and non-governmental agencies and their constituencies. In other words, adaptability depends on both the technological infrastructure, i.e., the reservoir system and its operating procedures, and the institutional arrangements within the system.

\section{Technological Infrastructure}

We examine the adaptability of the technological infrastructure by asking whether the Columbia River system could have been managed differently in the past to better optimize water distribution among all uses. The previous discussion showed that firm energy objectives have been essentially isolated from climate variability by the design of the operating system and the amount of energy production assigned to the hydro-system. In contrast, overall instream flow requirements for fisheries protection is one of the first objectives to be affected by low streamflow (Figure 4). Could the operating system be redesigned to satisfy both fisheries protection and energy production objectives?

The ColSim water resources model was used to evaluate a hypothetical alternative reservoir operating system design in which all major storage in the system (including Canadian treaty storage) was used to meet the instream flow targets set for McNary and Lower Granite dams by the 1995 Biological Opinion Agreement (NMFS, 1995). Rule curves and system objectives for all other water uses, including firm energy production and flood control, remain unchanged. The mean reliability (for 1931-1989) of meeting the McNary flow target increased from 86 percent, for the "status quo" operating system discussed above, to 99 percent for the alternate operating system (Table 4). However, this improvement in isolating flow target goals from the effects of climate variability was accompanied by corresponding reductions in the reliability of current levels of hydropower production and of other uses in the system. Mean reliability for meeting yearly-average, system-wide firm energy targets of $6.0 \times 10^{6} \mathrm{MWhr} /$ month decreased from $100 \%$ in the original system to 90 percent under the alternative operating system. The average simulated shortfall for firm energy production was $3,000,000 \mathrm{MWhr} /$ year. Impacts to other water uses

TABLE 4. Reliability of Meeting Columbia River Basin Water Resources System Objectives Under the Status Quo Operating System and an Alternative, Hypothetical Operating System Wherein System-Wide Instream Flow Targets are Supported by All System Storage. Reliability, or the probability of no failure, was determined using the ColSim model for the period 1931-1989 (see text). System objectives are as defined in Table 3.

\begin{tabular}{|c|c|c|}
\hline System Objective & $\begin{array}{c}\text { Reliability } \\
\text { Status Quo Operating } \\
\text { System (percent) }\end{array}$ & $\begin{array}{c}\text { Reliability } \\
\text { Alternative Operating } \\
\text { System (percent) }\end{array}$ \\
\hline $\begin{array}{l}\text { Hydropower Production } \\
\text { Firm Energy } \\
\text { Non-Firm Energy }\end{array}$ & $\begin{array}{r}100.0 \\
95.3\end{array}$ & $\begin{array}{l}90.2 \\
88.2\end{array}$ \\
\hline Flood Control & 98.4 & 98.6 \\
\hline $\begin{array}{l}\text { System-Wide Instream Flow Target } \\
\text { McNary Dam }\end{array}$ & 86.2 & 99.4 \\
\hline $\begin{array}{l}\text { Local Instream Flow Targets } \\
\text { Priest Rapids } \\
\text { Columbia Falls }\end{array}$ & $\begin{array}{l}100.0 \\
100.0\end{array}$ & $\begin{array}{l}94.7 \\
90.7\end{array}$ \\
\hline Agricultural Diversions (middle Snake River) & 90.1 & 90.1 \\
\hline Recreation & 90.7 & 81.8 \\
\hline Navigation & 91.8 & 91.8 \\
\hline
\end{tabular}


are shown in Table 4. Because of the conflicting timing for hydropower production and major instream flow targets, it is not possible to insulate both uses from climate variability within the current framework of water use objectives. Either instream flows for fisheries protection or current levels and timing of firm hydropower production can be fully protected from climate variability, but not both. Thus the current system cannot adapt to meet all of the current demands all of the time.

The Columbia River system, with more than 250 reservoirs and 100 hydroelectric projects, is one of the most highly developed in the world. It is generally considered to be a mature water management system with little room for future expansion or development. Under current assumptions and institutions there are very limited possibilities for changes in infrastructure, such as adding additional reservoir storage capacity to better meet conflicting demands.

Not only is it currently impossible to meet all water resources objectives, current institutional arrangements in the Columbia River Basin appear to preclude an organized and comprehensive management response that would optimize allocation of water.

\section{Institutional Arrangements}

Adaptability to Floods. Institutional arrangements in the Columbia River Basin relative to the overriding priority of flood control clearly facilitate adaptability. Because flood control was an original priority of the Columbia River system, as stipulated in the authorizing legislation for many of the storage dams (BPA et al., 1995), and flood-control management is centralized, adaptability is essentially ensured. There are only four major actors in this arena: the U.S. Army Corps of Engineers (ACOE), the U.S. Bureau of Reclamation (USBR), the Bonneville Power Administration (BPA) and Canadian Projects. The ACOE operates 22 U.S. federal dams, USBR operates nine and the BPA markets hydropower for all federal dams in the system. The ACOE is the primary decision-maker and the BPA, USBR and Canadian projects cooperate according to various agreements. The ACOE is closely linked with both the NOAA Regional River Forecast Center and the National Resource Conservation Service of the USBR for forecast information and flood control protocols that facilitate adaptability in high streamflow conditions (D. Laurine, River Forecast Center, Portland, Oregon, and P. Brooks, ACOE, Portland, Oregon, personal communications, 1996). With respect to flood control, there is no doubt about who is in charge of reservoir operations for all dams: it is the ACOE (BPA et al., 1995).
Adaptability to Droughts. The situation is quite different with respect to drought. The Columbia Basin, as a natural system, is uncler great stress because it cannot even now satisfy all demands made upon it (BPA et al., 1995). In drought conditions, junior water rights holders may not receive their full water allocations, hydropower companies can suffer substantial economic losses and low streamflows can harm fish stocks and habitat (Callahan et al., 1999). For example, the Roza irrigation district in the Yakima River Basin (a sub-basin of the Columbia) is a district comprised solely of junior water rights. Because of drought conditions in 1992, 1993 and 1994, water entitlements in Roza were reduced by 42,33 and 63 percent, respectively (Gray, 1999). This had significant impacts on the district's irrigated agriculture, which mostly comprises perennial fruit crops, such as tree fruits. In contrast, senior water rights holders in the Yakima Basin have always received their full water right (Gray, 1999). The allocation of junior and senior water rights among different water users and water districts is an artifact of the historical development of water projects.

Drought conditions exacerbate conflicts between hydropower production and fisheries protection interests. During 1987 and 1988, Snake River run-off was only $\sim 60$ percent of the 50 -year average (Wood, 1993). During this year, minimum instream flows in the Snake River were not provided. According to fisheries interests, base flows were retained by hydropower managers to satisfy their priorities of reservoir refill and flow shaping for power marketing, while power planning representatives maintained that the low flows were a result of the basin-wide drought conditions (Wood, 1993). Callahan et al. (1999) found that these kinds of institutional conflicts associated with limited supply were a general feature of Columbia Basin water resources management.

Can the current Columbia River water resource management system optimize water allocation among competing water uses in the region? The answer to that is a resounding "no" for several complex reasons. The water resource management system in the American part of the basin is large and fragmented. It includes a very large cast of managers at federal, regional, state, county, and municipal levels, plus fourteen Native American tribes. The management system also includes the constituents and pressure groups that have developed to advance the influence of interests in fisheries, hydropower, industry, transportation, irrigated agriculture, recreation and other users of the river. Without a primary decision-maker, such as the ACOE for flood control, the system remains highly disjointed. In addition, the agreements, legal requirements and coordinating processes for managing the Columbia River systems create a 
Pacific Northwest Regional Assessment: The Impacts of Climate Variability and

Climate Change on the Water Resources of the Columbia River Basin

complicated decision-making process that requires immense effort to alter. The primary governing agreements include the Columbia River Treaty, the Canadian Entitlement Allocation Agreement, the Pacific Northwest Coordination Agreement (PNCA), the Endangered Species Act, the Pacific Northwest Electric Power Planning and Conservation Act, and the Fish and Wildlife Coordination Act (Callahan et al., 1999).

Legal agreements (particularly PNCA) provide the authority for coordination in a highly decentralized system. Beyond meeting operational requirements, however, the management system responds very slowly to change. Coordination agreements, unresolved conflicts (e.g., between fisheries, in-stream flow for hydropower production, water rights) and other legal requirements constrain the flexibility of managers. This inertia increases the vulnerability of the system to climate variability (Callahan et al., 1999).

Under these conditions, any changes to systemwide operations require a huge bureaucratic effort; therefore short-term changes for only incremental improvements are unlikely. The fact that there is not enough water in the system to meet current needs all of the time, combined with current patterns of conflict between water users, implies that any changes to the water management system would redistribute impacts without resolving conflicts. In the event of efforts to initiate change, water users would therefore tend to become "polarized" within the legal and political sectors, depending on whether or not they stood to benefit from the proposed changes. This would create additional obstacles to change. A current example of this is the fight between farmers and environmentalists over the proposed breaching of several Snake River dams to restore salmon runs.

Western Water Law. Western water law presents another major hindrance to optimizing water use in the face of declining supply. Western water law was developed in the nineteenth century, is based on the concept of the prior appropriation rule, i.e., "first in use, first in rights," and favors use of water for irrigation (Dufford, 1995). This rule in its original form denied that connections exist between groundwater and surface water and that water left in the stream is of "beneficial use" (Dufford, 1995).

In the face of legal attacks by environmentalists and disparate groups seeking protection for fisheries, the prior appropriation rule has been amended so that the latter two denials are no longer operative (Dufford, 1995). Opponents to the rule are increasingly relying on the provisions of the Clean Water Act, the Endangered Species Act, and the Public Trust Doctrine (Johnson and Pascal, 1995). For example, in an appeal of a 1996 case involving the Washington
Department of Ecology (WDOE) versus approximately 150 developers, the State Pollution Control Hearings Board upheld the authority of WDOE to deny applications for rights to groundwater when for the purpose of protecting state fisheries (Taylor, 1996). The Board's decision was in turn upheld by the King County Superior Court in 1998 (Hopkins, 1998).

Western water law has proven to be very difficult to change (Illahee, 1995; Dufford, 1995). Current avenues for effecting change are voluntary transfers, such as leasing rights, which are both expensive and temporary; the courts; or State/Federal legislatures (Benson, 1995). The two routes in the courts, i.e., litigation or a general adjudication for a watershed, are time-consuming and expensive (Dufford, 1995). The latter route is being attempted for the Yakima Basin, but has already been in the courts for 18 years with experts predicting another nine years before there will be an outcome (Lehman, 1995). This is another example of the legal and political obstacles that emerge when proposed changes to the water resources management system threaten to redistribute impacts without resolving conflicts.

Difficulties will increase in the future with increases in regional population. Washington State population is projected to increase at an annual growth rate of about 1.3 percent from a population of approximately $5,900,000$ in the year 2000 to about $7,500,000$ in 2020 (Washington State Office of Financial Management, 1998). The projected increase is roughly equivalent to adding three cities the size of Seattle to the state in the next twenty years. Increased population, which will increase the demands placed on regional water resources, will present an additional barrier to adaptability, regardless of future patterns of climate variability or change. Without significant changes in water resources management and use patterns, projected population growth represents an increased stress on an already stressed system.

\section{HOW VULNERABLE IS THE COLUMBIA RIVER BASIN TO CLIMATE VARIABILITY?}

Vulnerability depends on both a system's sensitivity to climate variability and its ability to adapt. The sensitivity analysis of the Columbia River Basin indicated the increased probability of abnormally low streamflow during El Niño and/or warm PDO years. In addition, the reliability of meeting some system objectives, e.g., irrigation water supply for the middle Snake River and McNary fishery protection flow targets, decreases rapidly with decreasing streamflow under the current operating system and framework of water resources demands (Figure 4). The inertia 
of the fragmented management system, coupled with the inefficient allocation of water resulting from western water law, hinders adaptability to these conditions. Under current conditions, recreation, instream flow targets, agricultural diversions in the middle Snake River and, to a lesser degree, non-firm energy targets are vulnerable to climate variability because of the lack of adaptability in the system.

\section{Perceptions of Regional Managers}

Water resource managers' perceptions of the impacts of climate variability on the resources that they manage were identified in a 1996 survey of managers at 28 different organizations in the PNW (primarily within the Columbia Basin) (Callahan, 1997; Callahan et al., 1999). The survey consisted of 31 interviews conducted by three of us (Callahan, Fluharty and Miles) with individuals and groups of planners, hydrologists, engineers, climatologists, regulators and analysts in private, municipal, state, federal, and tribal organizations. The interviews included representatives from organizations concerned with hydropower production, fish and wildlife management, water quality and watershed management, flood control, irrigation, municipal and industrial water supply, and river navigation. The primary goal of the survey was to identify the degree to which managers incorporated climate forecast information into their operational decision making process (Callahan, 1997; Callahan et al., 1999). Managers were also asked to discuss the ways in which the resource(s) they manage were sensitive and vulnerable to climate variability and to characterize the most important climate-related vulnerabilities of the region. In the discussion that follows, the terms "drought" and "flood" are used to represent the extremes in low or high streamflow significant to each manager and do not necessarily represent a universal definition of hydrological conditions.

Regional water managers consider the Columbia River system to be most vulnerable to drought; 80 percent ranked drought as the region's primary climate-related issue of concern (Table 5). Drought ranked highest for managers of fish and wildlife, water quality and watersheds, navigation, irrigation, and hydropower production, as well as for those managing multiple water uses. Many managers stated that their vulnerability to drought had increased as a result of instream flow requirements for fisheries protection.

The specific reasons behind each group's concern with drought further illustrates the conflicts within the system. When water is scarce, the hydropower industry may suffer economic losses because of lost generation capabilities and the cost of buying power outside of the Columbia River system. Droughts exacerbate problems for salmon, such as low streamflow and water quality concerns, such as increased water temperature. Political pressure on hydropower and irrigation interests to protect fisheries intensifies during low flow periods when conflicts between the uses intensify. In the managers' perceptions, coalitions form among different uses with parallel objectives, thereby pitting hydropower, irrigation, municipal and industrial water supply, some recreation and some navigational interests against environmental and commercial interests seeking in-stream protection for fisheries, other recreational, and other navigational interests (Callahan et al., 1999). The dominance of flood control protocols in reservoir operations may benefit different interests at different times but, as discussed previously, the operational dominance of hydropower interests means that the others must fight over what is left.

A relative lack of storage in the reservoir system contributes to the perceived vulnerability of the Columbia River Basin to drought. The Columbia

TABLE 5. Ranked Primary Vulnerabilities Related to Climate Variability in the Pacific Northwest from a 1996 Survey of Water

Resource Managers at 28 Different Organizations in the Pacific Northwest, Mainly in the Columbia Basin (Callahan, 1997; Callahan et al., 1999). Vulnerabilities were defined as changes to which the water management system cannot adapt; all of the vulnerabilities shown here were perceived by water managers to be related to climate variability.

Water Management Vulnerability of Concern

Drought

Flooding

Low Storage Capacity in Reservoirs

Decline in Fisheries Stocks and Habitat

Water Quality Degradation
Number [and Percentage] of Respondents

Considering This Vulnerability Major $(\mathbf{N}=\mathbf{2 5})$ $\begin{aligned} 20 & {[80 \text { percent }] } \\ 15 & {[60 \text { percent] }} \\ 12 & {[48 \text { percent] }} \\ 8 & {[32 \text { percent] }} \\ 5 & {[20 \text { percent] }}\end{aligned}$ 
River can store only about 30 percent of its annual runoff in reservoirs, much less than the storage available on the Missouri and Colorado Rivers, for example (BPA et al., 1995). Inadequate storage was recognized as a major vulnerability by 12 out of 25 managers, all of whom have reservoir operational responsibilities.

The time scale of drought and storage vulnerability cited by the different water managers ranged from a single year to a decade. This range most likely indicated a loose and varying definition of drought and vulnerability between managers. Nonetheless, thresholds of management sensitivity to drought duration and intensity are likely to be different for different water users. These differences must be accounted for in regional assessments of climate impacts.

Regional managers are also concerned about the opposite end of the streamflow spectrum - floods. Despite the fact that much of the reservoir system was originally designed for flood control, 15 out of 25 managers interviewed considered the system either vulnerable to flooding or vulnerable as a result of flood control operations. Reservoir levels are drawn down for flood control in the fall to create storage for winter and spring runoff, a schedule that is generally compatible with winter hydropower production. Irrigation interests, who would like to store more of the fall and winter precipitation for use in the following growing season, are potentially in conflict (BPA et al., 1995).

While storage vulnerabilities were primarily associated with drought risks, the ACOE also views current storage capacity as a flood-related vulnerability. The Vanport, Oregon flood of 1948 was the largest of this century. During peak flows of $1,010,000$ cubic feet/second at The Dalles (approx. four times average streamflow) (USGS, 1949), a levee broke, destroying the town of Vanport, killing thirty-eight people, and causing $\$ 103$ million in property damage (White, 1995) (see Figure 1 for location). At the time, there were only two dams on the Columbia, Grand Coulee and Bonneville, neither of which was built for flood control. Subsequent flood-control reservoirs and coordination of flood control management has increased the Columbia River system's capability for decreasing peak flows and made the modern Columbia River system resilient to high flow conditions. High flows flooded some lowland areas in February 1996, but without the current flood control system, flows would have been at least as high as they were in 1948 (Stewart, 1998).

The decline in fisheries stocks and habitat and degradation of water quality were the remaining climate-related vulnerabilities considered to be of primary concern by regional managers (Table 5). Managers in fish and wildlife sectors perceived the fisheries-related vulnerability in terms of the negative effects of environmental and management conditions on salmon stocks. Managers in hydropower, flood control, forecasting, and irrigation felt that the major vulnerability resulted from the inflexible changes in the management requirements that were designed to help restore fish stocks.

All of the managers concerned about climate impacts to water quality had fish and wildlife, water quality, or watershed management responsibilities. The primary types of water quality problems discussed were overly warm temperatures (mainly a problem in summer), inadequate dilution of pollutants, and turbidity. All three are strongly affected by climate variables including temperature, precipitation, runoff, and the frequency and severity of storm events.

Within the Columbia River system we see, not surprisingly, that all of the uses, conflicts, and climaterelated vulnerabilities are intertwined. The primary issues of conflict in the Columbia River system are instream flow requirements, water rights, and reservoir operational conflicts between fisheries, recreation, irrigation and hydropower (Callahan et al., 1999). These conflicts arise from the way the water management system deals with variations in water supply caused by natural climate variability. Moreover, the operation of the water management system is embedded in, and currently inseparable from, those conflicts. The climate-related vulnerabilities of the Columbia River system - drought and low streamflow, inadequate storage in the reservoir system, floods, water quality degradation, declining fish stocks and habitat - are also closely related to the main issues of conflict. The tight relationships between the conflicted issues and climate-related vulnerabilities indicates that eliminating vulnerabilities will not be a matter of simply finding a technical solution, e.g., establishing new operating priorities for the water management system. Alternative management solutions will always result in situations with winners and losers and will therefore be politically difficult to implement.

\section{Strategies for Reducing Vulnerability}

The success of the Columbia River water management system at adapting to the threat of floods suggests that centralized management of the resource is a necessary condition for institutional adaptability to climate variability. Three additional criteria for an effective response to climate variability are managerial flexibility (including the ability to incorporate new information), development of institutional memory, and coordination. As described previously, current water resources management in the Columbia is based on a heuristic analysis of historical conditions 
(during August-December operations) and measurements of snowpack (during January-July). Recent improvements in long-range streamflow forecasting based on PDO and ENSO climate signals suggest that these kinds of forecasts could increase the flexibility of the Columbia River management system in fall and early winter (Hamlet and Lettenmaier, 1999a; Leung et al., 1999).

When the development of institutional memory is encouraged, a water resources management system that learns how climate variability has affected it in the past has the potential to improve its operations under similar conditions in the future. Institutional memory played a prominent role in the Seattle Public Utilities' development of a successful drought response policy. After being challenged by significant droughts in 1987 and 1992 (both El Niño years), the utility responded quickly when a strong El Niño event was predicted for 1998. Actions taken to augment supply and storage and reduce demand successfully precluded negative impacts to water users during the significantly low streamflows that occurred in 1998 (Gray, 1999).

A coordinated management system that allows costs and benefits to be shared and/or traded among users of the water resource encourages flexibility and adaptability to climate variations. Hydropower production throughout the Columbia River Basin is coordinated (under the PNCA) as if the total system had a single owner (BPA et al., 1995). This coordination provides the flexibility necessary to respond to climate variability by encouraging, for example, operational decisions that shift energy production to parts of the system that have more available water in storage. In contrast, the irrigation districts of the Yakima Basin are operated essentially independently, with little basin-wide coordination. When low streamflow conditions occur, each district copes as well as possible on a local level, but largely in isolation (Gray, 1999).

\section{IMPACT OF FUTURE CLIMATE CHANGE IN THE COLUMBIA RIVER BASIN}

The analysis of the impacts of climate variability in the Northwest provides a foundation for an examination of potential regional consequences of future climate change. Our analysis of climate variability showed that the dominant impact pathway was via the regional hydrology, specifically through the influence of wintertime temperature and precipitation on snow pack and streamflow (Figure 2). If future regional climate projections resemble temperature and precipitation changes like those observed in the past, or have similar impacts to snow pack and streamflow, the impacts of such a change in climate can be readily estimated.

We examine the implications of future climate change by comparing the impacts of projected changes in temperature and precipitation derived from two global climate model simulations archived by the IPCC. The climate simulations examined here were produced by the Max Planck Institute (MPI) (ECHAM4 climate model, see Cubasch et al., 1992 for a description of earlier models) and the U.K. Meteorological Office Hadley Centre (HC) (HadCM2 model, Johns et al., 1997). These models each assume a 1 percent annual compound increase irl $\mathrm{CO}_{2}$, and both include the effects of sulphate aerosols. The time scales chosen for this intercomparison were the decades centered on 2025 and 2045. The climate change signal predicted by these models is presented here as a Columbia River basin-wide spatially averaged change in temperature or precipitation relative to the respective model's control run for each month. Details on the downscaling methods used to obtain these averages can be found in Hamlet and Lettenmaier (1999b).

The MPI and HC simulations show different rates of warming and different precipitation patterns in the Columbia River Basin (Figure 5). The two models predict increased temperatures for all months of both 2025 and 2045. Despite month-to-month differences, average winter and summer temperature increases are relatively consistent between the models. For precipitation, the two models predict significantly different patterns of changes, especially during the summertime (Figure 5).

These model scenarios represent only regional and monthly average temperature and precipitation changes. Although climate models are not currently capable of simulating how climate variability would be affected by future climate change, our study of water resources in the Columbia River Basin indicates that for the current climate it is climate variations that are of concern to water resource managers. It is when streamflow diverges from the mean that water users experience impacts. 'Thus, although future changes in mean streamflow are important, so, too, is how streamflow may vary in the future.

In order to examine the impacts of future climate change, we therefore apply projections of future climate changes to the historical record of PNW climate. In this way, we can examine the implications of climate change for streamflow and water resources objectives in the Columbia River Basin, within the context of our current understanding of the natural patterns of climate variability. The general procedures are as follows (for specific details, see Hamlet and Lettenmaier, 1999b). The projected monthly changes in basin-average temperature and 

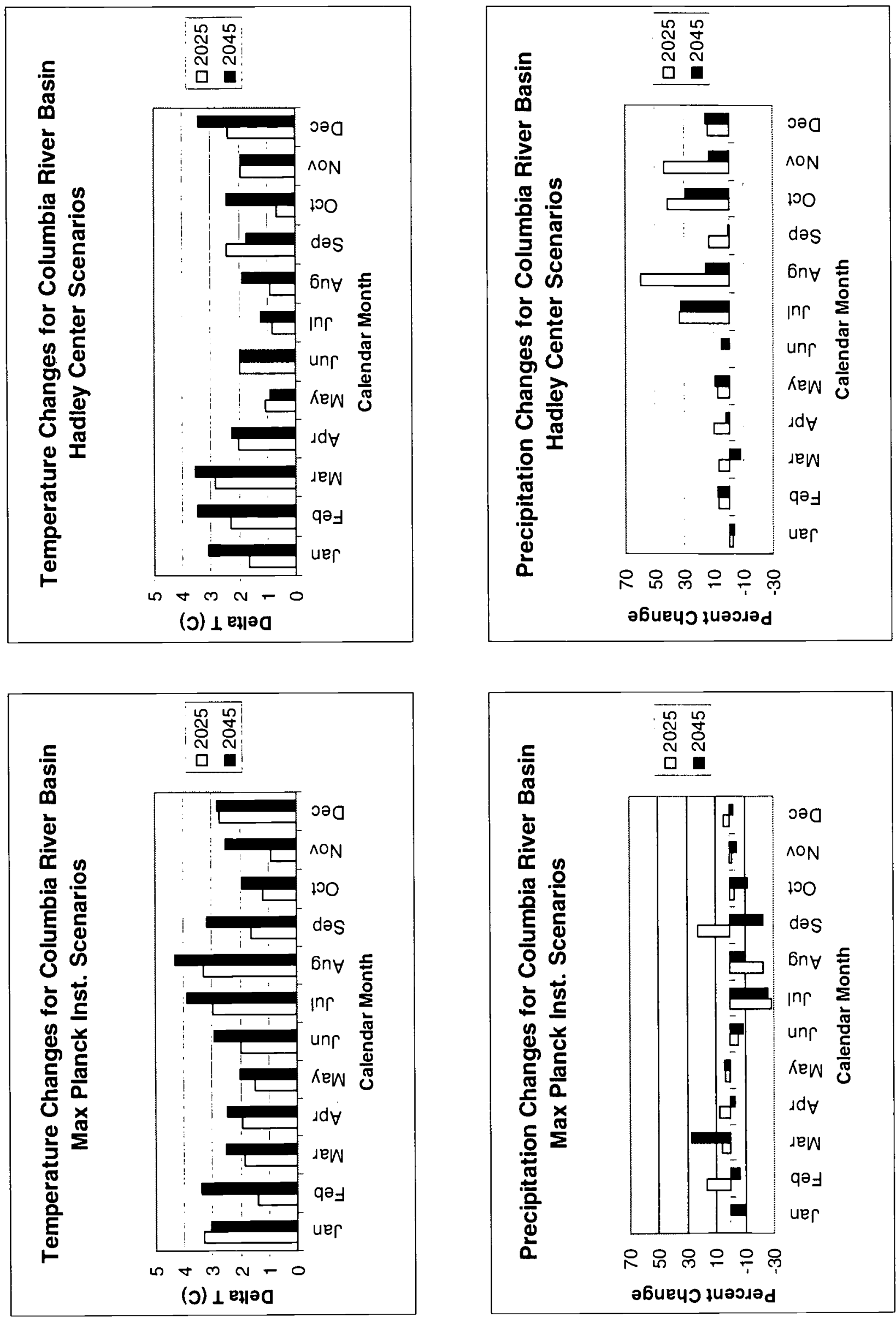
precipitation, derived from the climate simulations (Figure 5), are used to perturb the historical record of PNW temperature and precipitation. This perturbation is uniform over each calendar month and the entire basin. Historical temperature and precipitation records were derived from PNW climate station data from 1961 to 1997 , interpolated to $1 / 8$ degree (latitude/longitude) over the Columbia River Basin. The perturbation changes the long-term mean of the historical record for each calendar month, but preserves most aspects of the observed climate variability. For example, the observed relationships between daily maximum and minimum temperatures are preserved, as is the relative spatial variability of precipitation and temperature throughout the basin. The perturbation is done separately for the climate change projections for 2025 and 2045, resulting in three time series of regional temperature and precipitation, i.e., the base case (unperturbed), 2025 and 2045.

Each time series was used to drive a 1/8 degree resolution Variable Infiltration Capacity (VIC) hydrology model developed at the University of Washington and Princeton University (Liang et al., 1994; Nijssen et al., 1997; Matheussen et al., 1999). The VIC model has been widely used for simulation of regional-scale watersheds in North America and Europe (see for example, Abdulla et al., 1996, and Lohmann et al., 1998). Because the VIC model simulates well the effects of variability in temperature and precipitation on observed Columbia River streamflow for the historical record (Hamlet and Lettenmaier, 1999b), it is expected to be similarly skilled at simulating the effects of the relatively small changes in temperature and precipitation projected for 2025 and 2045 .

Composite hydrographs for the Columbia River for each time series show the consequences of the changes in temperature and precipitation predicted by the climate simulations (Figure 6 ). The quantitative effects to streamflow are significantly different for the two climate models, however the qualitative effects to seasonal patterns of streamflow are relatively consistent. The consequence of the projected climate changes is higher flows during the winter and spring, and lower flows during the summer and fall. The tendency towards more precipitation and warmer temperatures during the winter (Figure 5) implies substantially more rain, less snow pack accumulation, and therefore increased wintertime runoff. The decrease in snow pack accumulation, combined with lower summertime precipitation and higher summertime temperatures and evapotranspiration, lead to decreased summertime flows (Hamlet and Lettenmaier, 1999b). The timing of flows is also altered. Peak spring flows tend to begin earlier compared to current runoff patterns (Figure 6). (a)

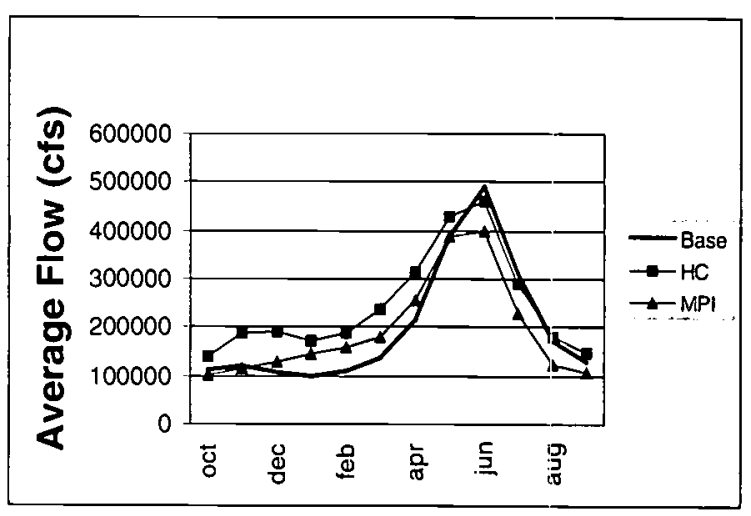

(b)

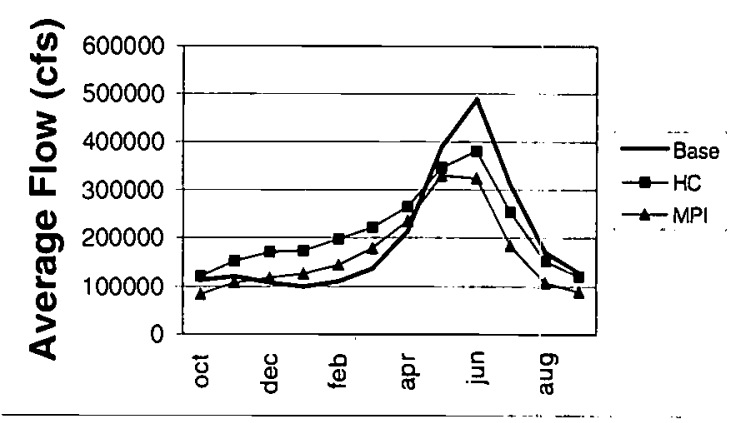

Figure 6. Composite Columbia Basin hydrographs (average for each calendar month) for the Columbia River at The Dalles Resulting from the Climate Changes Simulated by MPI and HC (shown in Figure 4): (a) 2025 and (b) 2045.

The base case represents the composite simulated historical hydrograph for 1961 to 1997 . The composite hydrographs for 2025 and 2045 represent the effects to streamflow of perturbing the historical record of temperature and precipitation by the climate changes simulated by the climate models (see text).

The impacts of these projected changes in flow regime on the water resources objectives of the Columbia River Basin were examined using the ColSim reservoir simulation model. An estimate of the reliability of meeting water resources system objectives was developed for the time series representing the base case, 2025 and 2045. The MPI scenarios, which result in the largest decreases in summertime streamflow (Figure 6), produce the greatest impacts to the system uses that are sensitive to decreased flow in that season. The performances of energy production, flow targets, agricultural irrigation and recreation are all significantly degraded for the MPI scenarios (Figure 7). Because of the smaller resultant 


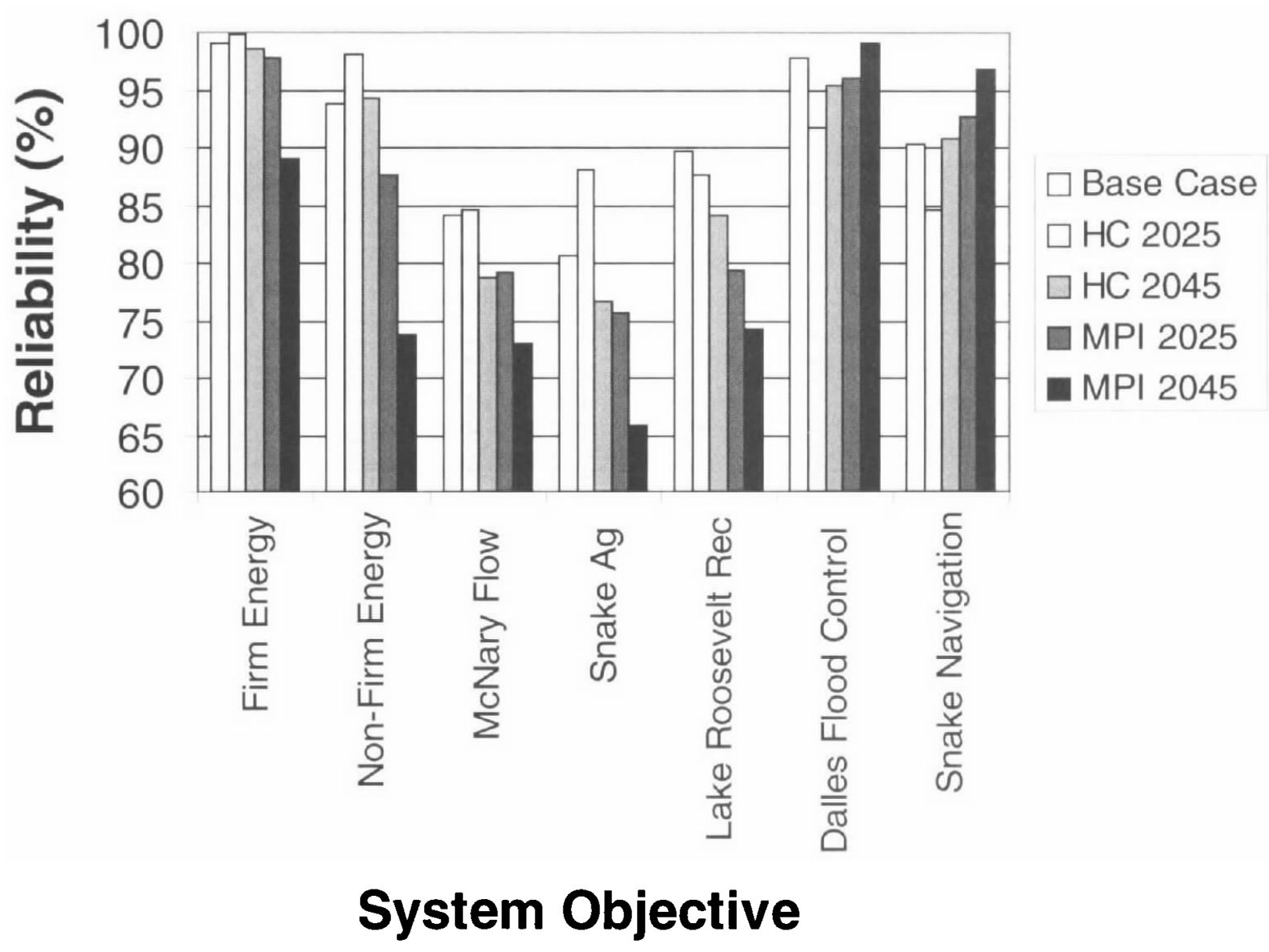

Figure 7. Effects to the Reliability of Columbia River Water Resources Objectives Simulated by the ColSim Model for the Climate Change Simulations Compared to the Base Case.

changes to summer streamflow, the HC simulations caused smaller impacts to these uses, especially for 2025. In contrast, the decreased summertime flows resulting from the MPI scenarios tended to improve the system performance with respect to reliability of desirable navigation conditions and flood control at The Dalles, i.e., uses that are enhanced by lower flows. Under the HC simulations, the reliability of these uses was reduced due to the large predicted increases in fall and winter precipitation volumes. For HC simulations, energy production capability was enhanced or essentially unchanged from the base case (Figure 7).

This analysis assumed no change in the current Columbia Basin operating policies nor in the various demands on the system in the future. For example, no adjustments were made to the operational rule curves governing energy production and reservoir evacuation for flood control to account for the altered timing of peak flows under climate change (Figure 6). Climate change or other factors may also significantly affect demand; such changes could affect the frequency, severity, and duration of impacts. It is possible that some of the impacts detailed above might be mitigated with adaptive management or physical system modifications.

We emphasize that there are considerable uncertainties in the climate model results described above. However, consistent features in the model scenarios include a qualitative shift in the PNW to warmer, wetter winters with less snow and more rain. That shift presages future regional vulnerability. Most of the region's water storage capacity is represented by winter snow pack: total reservoir storage capacity in the Columbia River Basin is limited to 30 percent of total flow (BPA et al., 1995). As snow pack declines, so will management options for responding to projected future growth in demand under current system constraints. Conflict between uses is likely to increase, but the Columbia River water resources system is unable to resolve conflicts between water resources objectives in low streamflow situations, 
even for the current climate. For example, low streamflow in water year 1992 resulted in a net loss of approximately $\$ 273$ million for the Bonneville Power Administration (BPA et al., 1994) and created serious water shortages in several other water resources systems in the PNW including the Yakima River basin (Gray, 1999). Taking summer streamflows in water year 1992 as a drought threshold, Hamlet and Lettenmaier (1999b) showed that the frequency of simulated summer streamflow sequences below this threshold nearly doubled by 2045 for the HC scenario and more than quadrupled by 2045 for the MPI scenario, relative to the base case.

It is important to note once again that the climate model scenarios only indicate how regional average temperature and precipitation might change; they do not address how climate variability would be affected by climate change. Our analysis uses the projections of changes in average climate with an assumption that the patterns of climate variability in the PNW remain unchanged in the future to examine the effect of a shift in mean temperature and precipitation in the context of observed natural variability. Climate change, however, may manifest itself through changes in ENSO, the PDO and/or other natural modes in the climate system, resulting in altered patterns of climate variability. Although climate models currently project gradual climate change, there is also a possibility that the climate system may respond in surprising and/or sudden and unforeseen ways (IPCC, 1996a; Broecker, 1987, 1997). There is still much uncertainty over whether and/or how global climate change will alter natural patterns of climate variability.

On-going natural climate variability will have major implications for monitoring future climate and developing policy responses to anthropogenic climate change. Monitoring and policy changes based solely on short-term observations of climate, without regard for patterns of variability like the PDO, are likely to be ineffective or even detrimental to a long-term strategic response to a changing climate.

\section{CONCLUSIONS}

Large scale patterns of climate variability, i.e., ENSO and the PDO, have exerted considerable influence on PNW climate for at least the past 120 years, primarily through atmospheric and oceanic circulation changes favoring either cool and wet or warm and dry PNW winter and spring seasons (Redmond and Koch, 1991; Mantua et al., 1997). The PNW is highly sensitive to these patterns of climate variability as evidenced by the resultant variations in Columbia River streamflow (Figure 3).
Under the current operating system in the Columbia River Basin, the water uses most sensitive and therefore most vulnerable to climate variability are (in descending order): McNary flow target for fisheries protection, Lake Roosevelt recreation, navigation, non-firm energy, and middle Snake River agricultural diversions. Firm energy and flood control are the most protected activities in the main stem of the Columbia. In spite of legislation mandating greater protection for anadromous fish populations, our analysis shows that overall Columbia River instream flow requirements have a very low de facto priority within the current water resources operating system. These are only fully satisfied in years with close to, or higher than, average streamflows. While system-operating procedures could be revised to make instream flow targets insensitive to climate variability, this could be accomplished only by increasing impacts to other system objectives (Table 4).

Adaptability to the threat of floods is high in the main stem of the Columbia, given the existence of centralized authority, adequate technological infrastructure, and good working relationships between the dominant players. Adaptability in the face of droughts, however, is limited. When water supply decreases, conflict increases and the system lacks the necessary centralized authority to optimize declining supply. This absence of authority is exacerbated by the allocation of water rights under the prior appropriation rule. In general, conflict between in-stream and out-of-stream uses is intensifying (Lee, 1995), due to increasing consumptive demand and instream flow requirements. Climate variability brings additional stresses to a system already highly stressed by anthropogenic activities.

Vulnerabilities under current patterns of climate variability are greatest in relation to the extremes of high and low streamflow. Addressing the climaterelated vulnerabilities of the water resources system is impeded by the high level of conflict between competing water uses. Any attempts to rework the technical and/or management systems to better coordinate water use objectives will be hindered by the fact that there is currently not enough water to satisfy all of the users all of the time. Reallocation of water resources would move impacts from one user to another, polarizing the water users and creating political obstacles to change.

With respect to the future climate, we reiterate the power of the integrated regional assessment framework. By elucidating the pathways through which natural variations in regional climate are manifested as vulnerabilities in natural and human systems, we suggest how the same systems may respond to future climate change. In other words, we can hypothesize 
about the future once (but not before) we understand the present.

The model simulations of future climate examined here result in significantly decreased summertime streamflow as a result of decreased storage of precipitation as snow. Thus, patterns of summer streamflow under climate change would be similar to those currently occurring during El Niño and warm PDO years (compare summertime flow in Figures 3 and 6). This implies heightened conflict between water uses in the future. The inflexibility of the water management system will significantly impact the ability of the PNW to cope with these future changes. Without reforms in water use practices or water law, increased population densities also imply expanding conflict over water supply. Increases in demand may further limit the flexibility of the water management system to adapt to climate change by intensifying conflicts between water users.

We believe that an understanding of the dynamics of regional climate variability and its impacts must, and now can, underlie the design of policies for water resources management for the 21 st century. Previous studies have shown that climate forecast information is little used in PNW resource management decision making processes (Pulwarty and Redmond, 1997; Callahan et al., 1999). The Climate Impacts Group is working to educate managers and policy makers throughout the PNW about the links between climate variability, streamflow, and impacts to water resources. By understanding these linkages, managers will be in a better position to utilize climate information in decision making.

The case studies examined here identify four elements necessary for an effective response to climate variability and change: centralized management of the resource, managerial flexibility and the ability to incorporate new information, development of institutional memory, and coordination. While a few aspects of water management in the PNW have all of these desirable features, much work remains at the regional level to improve the adaptability of water resource management to climate variability and change.

Current projections of how climate will change in the future as a result of increasing atmospheric concentrations of greenhouse gases are insufficiently certain to be used as climate predictions. Nonetheless, the results presented here indicate that even relatively small changes in regional temperature and precipitation can have significant impacts on both the Columbia River flow regime and water resource objectives in the region. As regional climate changes, continuing to base water resource management decisions on an analysis of historical conditions is likely to become increasingly inadequate and inappropriate.
Upon what information should water resource managers base their operating decisions in a changed climate? Given the difficulty of changing operating procedures in the complex and fragmented Columbia Basin water management system, the implications of alternative decision making frameworks, such as using streamflow forecasts that incorporate the effects of climate change to generate annual rule curves, should be explored.

Finally, the best management and planning of today will be done with an eye towards both natural patterns of climate variability and possible future changes in climate. Monitoring programs and policy response strategies that follow only short-term climate trends will be ineffective at best and are likely to encumber a long-term strategic response to the changing climate by either overestimating or underestimating the true long-term trends.

\section{ACKNOWLEDGMENTS}

This publication is funded by the Joint Institute for the Study of the Atmosphere and Ocean (JISAO) (Contribution No. 690) under the NOAA Cooperative Agreement No. NA67RJ0155. The views expressed herein are those of the authors and do not necessarily reflect the views of NOAA or any of its subagencies.

\section{LITERATURE CITED}

Abdulla, F. A., D. P. Lettenmaier, E. F. Wood, and J. A. Smith, 1996. Application of a Macroscale Hydrologic Model to Estimate the Water Balance of the Arkansas-Red River Basin. J. Geophys. Res. 101(D3):7544-7549.

Benson, R. D., 1995. Water Rights Deals, Water Law Reform Restoring Water to Northwest Rivers. Illahee 11(1,2):29-39.

Bonneville Power Administration, U.S. Army Corps of Engineers (North Pacific District), Bureau of Reclamation (Pacific Northwest Region), 1991. The Columbia River System: The Inside Story. Report published for the Columbia River System Review by the U.S. Army Corps of Engineers and the Bureau of Reclamation.

Bonneville Power Administration, U.S. Army Corps of Engineers (North Pacific District), Bureau of Reclamation (Pacific Northwest Region), 1994. Daily/Hourly Hydrosystem Operation: How the Columbia River System Responds to Short-Term Needs. Report published for the Columbia River System Review by the U.S. Army Corps of Engineers and the Bureau of Reclamation. Report No. DOE/BPA-2000.

Bonneville Power Administration, Bureau of Reclamation and U.S Army Corps of Engineers, 1995. Columbia River System Operation Review: Final Environmental Impact Statement. U.S. Department of Energy Report No. DOE/EIS-0170.

Broecker, W. S., 1987. Unpleasant Surprises in the Greenhouse? Nature 328:123-126.

Broecker, Wallace S., 1997. Thermohaline Circulation, the Achilles Heel of Our Climate System: Will Man-Made $\mathrm{CO}_{2}$ Upset the Current Balance? Science 278:1582-1588.

Callahan, B. M., 1997. The Potential of Climate Forecasts for Water Resource Management in the Columbia River Basin. M.M.A. Thesis, University of Washington. 
Callahan, B., E. Miles, and D. Fluharty, 1999. Policy Implications of Climate Forecasts for Water Resources Management in the Pacific Northwest. Policy Sciences (in press).

Crook, A. G. Company, 1993. 1990 Level Modified Streamflow 19281989. Report to Bonneville Power Administration.

Cubasch, U., K. Hasselmann, H. Höck, E. Maier Reimer, U. Mikolajewica, B.D. Santer and R. Sausen, 1992. Time-Dependent Greenhouse Warming Computations With a Coupled OceanAtmosphere Model. Clim. Dyn. 8:55-69.

Dufford, W., 1995. Washington Water Law: A Primer. Illahee 11(1,2):29-39.

Gershunov, A. and T. P. Barnett, 1998. Interdecadal Modulation of ENSO Teleconnections. Bull. Am. Meteorol. Soc. 79:2715-2725.

Gray, K. N., 1999. The Impacts of Drought on Yakima Valley Irrigated Agriculture and Seattle Municipal and Industrial Water Supply. M.M.A. Thesis, University of Washington.

Hamlet, A. F. and D. P. Lettenmaier, 1999a. Columbia River Streamflow Forecasting Based on ENSO and PDO Climate Signals. Amer. Soc. Civ. Eng. (in press).

Hamlet, A. F. and D. P. Lettenmaier, 1999b. Effects of Climate Change on Hydrology and Water Resources Objectives in the Columbia River Basin. J. Amer. Wat. Res. Assoc. (in press).

Hopkins, J., 1998. State Can Limit Access to Ground Water. Seattle Post-Intelligencer, July 20, 1998.

Illahee, 1995. Journal for the Northwest Environment 11(1,2). Special Issue on Water in the West.

Intergovernmental Panel on Climate Change (IPCC), 1996a. Climate Change 1995. In: The Science of Climate Change, J. T. Houghton, L. G. Meira Filho, B. A. Callader, N. Harris, A. Kattenberg, and K. Maskell (Editors). Contribution of Working Group I to the Second Assessment Report of the Intergovernmental Panel on Climate Change, Cambridge University Press, New York, New York, Vol. I.

Intergovernmental Panel on Climate Change (IPCC), 1996b. Climate Change 1995. In: Impacts, Adaptations and Mitigation of Climate Change: Scientific-Technical Analyses, R. T. Watson, M. C. Zinyowera, and R. M. Moss (Editors). Contribution of Working Group II to the Second Assessment Report of the Intergovernmental Panel on Climate Change. Cambridge University Press, New York, New York, Vol. II.

Johnson, R. W. and R. Paschal, 1995. The Limits of Prior Appropriation. Illahee 11(1,2):29-39.

Johns, T. C., R. E. Carnell, J. F. Crossley, J. M. Gregory, J. F. B. Mitchell, C. A. Senior, S. F. B. Tett, and R. A. Wood, 1997, The Second Hadley Centre Coupled Ocean-Atmosphere GCM: Model Description, Spinup and Validation. Climate Dynamics 13:103134.

Lee, K. N., 1995. Deliberately Seeking Sustainability in the Columbia River Basin. In: Barriers and Bridges to the Renewal of Ecosystems and Institutions, L. H. Gunderson, C. S. Holling, and S. S. Light (Editors). Columbia University Press, New York, New York, pp. 214-238.

Lehman, R., 1995. Abdicating Responsibility for the Holy Grail of Consensus. Illahee 11(1,2):29-39.

Lettenmaier, D. P., D. Ford, S. M. Fisher, J. P. Hughes, and B. Nijssen, 1996. Water Management Implications of Global Warming: 4. The Columbia River Basin. Report to IWR, U.S. Army Corps of Engineers, and the Potomac River Commission.

Leung, L. R., A. F. Hamlet, D. P. Lettenmaier, and A. Kumar, 1999. Simulations of the ENSO Hydroclimate Signals in the Pacific Northwest Columbia River Basin. Bull. Amer. Met. Soc. (in press).

Liang, X., D. P. Lettenmaier, E. F. Wood, and S. J. Burges, 1994. A Simple Hydrologically Based Model of Land Surface Water and Energy Fluxes for General Circulation Models. J. Geophys. Res. 99(D7):14,415-14,428
Lohmann, D., E. Raschke, B. Nijssen, and D. F'. Lettenmaier, 1998. Regional Scale Hydrology. II. Application of the VIC-2L Model to the Weser River, Germany. Hydrological Sciences - Journal des Sciences Hydrologiques 43(1): 143-158.

Matheussen, B., R. L. Kirschbaum, I. A. Goodman, G.M . O'Donnell, and D. P. Lettenmaier, 1999. Effects of Land Cover Change on Streamflow in the Interior Columbia River Basin. Hydrological Processes (in press).

Mantua, N. J., S. R. Hare, Y. Zhang, J. M. Wallace, and R. C. Francis, 1997. A Pacific Interdecadal Climate Oscillation With Impacts on Salmon Production. Bull. Amer. Met. Soc. 78(6): 1069-1079.

Minobe, S. 1997. A 50-70 Year Climatic Oscillation Over the North Pacific and North America. Geophys. Res. Lett. 24:683-686.

National Marine Fisheries Service (NMFS), 1995. Biological Opinion: Reinitiation of Consultation on 1994-1998 Operation of the Federal Columbia River Power System and Juvenile Transportation Program in 1995 and Future Years. Endangered Species Act, Section 7 Consultation. National Marine Fisheries Service, Northwest Region, March 2, 1995.

National Research Council, 1998. Decade-to-Century Scale Climate Variability and Change. National Academy Press, Washington, D.C., $142 \mathrm{pp}$. (http://www.nap.edu).

Nijssen, B., D. P. Lettenmaier, X. Liang, S. W. Wetzel, and E. F. Wood, 1997. Streamflow Simulation for Contintental-Scale River Basins. Water Resour. Res. 33(4):711-724.

Pulwarty, R. S. and K. T. Redmond, 1997. An Assessment of the Role of Climate Forecasts in the Management of Salmon, Water and Hydropower in the Columbia River Basin. Bull. Amer. Met. Soc. 78:381-397.

Rasmussen, E. M. and J. M. Wallace, 1983. Meteorological Aspects of the El Niño/Southern Oscillation. Science 222:1195-1202.

Redmond, K. T. and R. W. Koch, 1991. Surface Climate and Streamflow Variability in the Western United States and Their Relationship to Large Scale Circulation Indices. Water Resour. Res. 27:2381-2399.

Stewart, B., 1998. Another Vanport Flood Possible But Not Likely. The Oregonian, May 25, 1998.

Taylor, R., 1996. State Control Over Water Strengthened. Seattle Post-Intelligencer, July 17, 1996, pp. A1-A5.

Trenberth, K. E., 1997. The Definition of El Niño. Bull. Amer. Meteor. Soc. 78:2771-2777.

United States Geological Survey, 1949. Floods of May-June 1948 in the Columbia River Basin. Water Supply Paper 1080, U.S. Department of the Interior.

Washington State Office of Financial Management, 1998. State of Washington State Population by Age and Sex: 1990-2020, November 1998 Forecast. Washington State Office of Financial Management, Forecasting Division (October).

White, Richard, 1995. The Organic Machine. Hill and Wang, New York, New York.

Wood, C. A., 1993. Implementation and Evaluation of the Water Budget. Fisheries 18:6-17.

Yevdjevich, V. M., 1963. Fluctuations of Wet and Dry Years. Part I: Research Data Assembly and Mathematical Models. CSU Hydrology Papers, No. 1.

Zhang, Y., J. M. Wallace, and D. S. Battisti, 1997. ENSO-Like Interdecadal Variability: 1900-93. J. Climate 10:1004-1020. 